\title{
The metabolism of neuropeptides
}

The hydrolysis of peptides, including enkephalins, tachykinins and their analogues, by endopeptidase-24.11

\author{
Rebecca MATSAS, A. John KENNY and Anthony J. TURNER \\ M.R.C. Membrane Peptidase Research Group, Department of Biochemistry, University of Leeds, \\ Leeds LS2 9JT, U.K.
}

(Received 19 April 1984/Accepted 2 July 1984)

\begin{abstract}
Endopeptidase-24.11 (EC 3.4.24.11), purified to homogeneity from pig kidney, was shown to hydrolyse a wide range of neuropeptides, including enkephalins, tachykinins, bradykinin, neurotensin, luliberin and cholecystokinin. The sites of hydrolysis of peptides were identified, indicating that the primary specificity is consistent with hydrolysis occurring at bonds involving the amino group of hydrophobic amino acid residues. Of the substrates tested, the amidated peptide substance $\mathrm{P}$ is hydrolysed the most efficiently $\left(K_{\mathrm{m}}=31.9 \mu \mathrm{M} ; k_{\text {cat. }}=5062 \mathrm{~min}^{-1}\right)$. A free $\alpha$ carboxy group at the $C$-terminus of a peptide substrate is therefore not essential for efficient hydrolysis by the endopeptidase. A large variation in $k_{\text {cat. }} / K_{\mathrm{m}}$ values was observed among the peptide substrates studied, a finding that reflects a significant influence of amino acid residues, remote from the scissile bond, on the efficiency of hydrolysis. These subsite interactions between peptide substrate and enzyme thus confer some degree of functional specificity on the endopeptidase. The inhibition of endopeptidase- 24.11 by several compounds was compared with that of pig kidney peptidyldipeptidase A (EC 3.4.15.1). Of the inhibitors examined, only $N-[1(R, S)$ carboxy-2-phenylethyl]-Phe-p-aminobenzoate inhibited endopeptidase- 24.11 but not peptidyldipeptidase. Captopril (D-3-mercapto-2-methylpropanoyl-L-proline), Teprotide (pGlu-Trp-Pro-Arg-Pro-Gln-Ile-Pro-Pro) and MK422 $\{N-[(S)-1$-carboxy-3phenylpropyl]-L-Ala-L-Pro $\}$ were highly selective as inhibitors of peptidyldipeptidase. Although not wholly specific, phosphoramidon was a more potent inhibitor of endopeptidase-24.11 than were any of the synthetic compounds tested.
\end{abstract}

The kidney brush-border membrane is a rich source of peptidases, one of which is endopeptidase-24.11 (EC 3.4.24.11). It is now clear that this enzyme is widely distributed in mammalian tissues (Kenny \& Fulcher, 1983), and it is found in brain membrane fractions where it is the enzyme responsible for hydrolysis of the $\mathrm{Gly}^{3}-\mathrm{Phe}^{4}$ bond of enkephalin (Matsas et al., 1983), an activity that

Abbreviations used: CPAB, $N-[1(R, S)$-carboxy-2phenylethyl]-Phe-p-aminobenzoate; DiMeC7, pGluGln-Phe-MePhe-MeGly-Leu-MetNH ${ }_{2}$, where pGlu represents 5-oxopyrrolidine-2-carboxylic acid; Hepes, 4(2-hydroxyethyl)-1-piperazine-ethanesulphonic acid; Hip-His-Leu, benzoylglycyl-histidyl-leucine; h.p.l.c., high-performance liquid chromatography; Nle, norleucine; MK422, $N-[(S)$-1-carboxy-3-phenylpropyl]-L-AlaL-Pro; SQ14225, D-3-mercapto-2-methylpropanoyl-Lproline; SQ20881, pGlu-Trp-Pro-Arg-Pro-Gln-Ile-ProPro; UK55076, $(S)$-HomoPhe-[N]-L-Phe- $\beta$-Ala. has been termed 'enkephalinase' (Schwartz et al., 1981; Schwartz, 1983). The identity of brain 'enkephalinase' with endopeptidase-24.11 was first indicated by (i) their similar substrate specificity, hydrolysing bonds involving the amino groups of hydrophobic residues, and (ii) their sensitivity to inhibition by the compounds phosphoramidon [ $N$-( $\alpha$-L-rhamnopyranosyloxyhydroxyphosphinyl)L-leucyl-L-tryptophan] and thiorphan [ $N$-(DL-2benzyl-3-mercaptopropionyl)glycine] (Fulcher et al., 1982; Matsas et al., 1983). Further confirmation of identity has come from immunological experiments (Matsas et al., 1983; Relton et al., 1983; Almenoff \& Orlowski, 1984), particularly the use of a monoclonal antibody to the kidney endopeptidase for purification of the brain enzyme by immunoaffinity chromatography (Relton et al., 1983). The purified brain enzyme resembles the forms purified from kidney and intestine in all 
respects save for a small difference in subunit $M_{\mathrm{r}}$ and in the pattern of glycosylation (Relton et al., 1983; Almenoff \& Orlowski, 1984).

Because of the possible significance of the brain enzyme in the synaptic inactivation of enkephalin (Schwartz, 1983), much attention has focused on this aspect of enzyme action, particularly with regard to the development of selective inhibitors (Roques et al., 1980; Hudgin et al., 1981 ; FourniéZaluski et al., 1982; Mumford et al., 1982). This tendency has implied an exclusive role for the enzyme in enkephalin metabolism in the central nervous system and has distracted attention from its more general role in metabolizing other biologically active peptides (see, e.g., Matsas et al., 1983). In addition, it has led to the viewpoint that the enzyme functions as a peptidyldipeptidase, hydrolysing a dipeptide from the $C$-terminus of a peptide (Malfroy \& Schwartz, 1982), rather than as a true endopeptidase. In this respect, the enzyme would resemble peptidyldipeptidase $A$ (angiotensin I-converting enzyme, EC 3.4.15.1). We have questioned this assumption on the grounds that the enzyme clearly acts as an endopeptidase in the hydrolysis of insulin B-chain (Kerr \& Kenny, 1974), substance P (Matsas et al., 1983) and some synthetic substrates (Almenoff \& Orlowski, 1983). This nomenclature is not merely a question of semantics, but is of fundamental importance when considering the mechanism of action of the enzyme and its likely specificity for peptide hydrolysis.

Much of the available information on the specificity of endopeptidase-24.11 has involved the use of crude brain membrane preparations. 'Affinities' for different peptides have often been assessed merely by the relative potency of the peptides to inhibit hydrolysis of $\left[T^{2} r^{1-3} \mathrm{H}\right]-$ enkephalin. Specific points of hydrolysis have rarely been identified and absolute rates of hydrolysis have usually not been measured. Even for enkephalin as a substrate, reported $K_{\mathrm{m}}$ values have varied in the literature from less than $0.1 \mu \mathrm{M}$ up to $124 \mu \mathrm{M}$ (Malfroy et al., 1978; Rush \& Hersh, 1982). These large discrepancies are partly a consequence of using, as source of enzyme, preparations that contain as contaminants other kinetically significant activities, particularly large amounts of aminopeptidases.

The identity of brain and kidney endopeptidase24.11 (Relton et al., 1983) justifies the use of the much more abundant kidney enzyme for defining the kinetics of hydrolysis of peptides. In the present paper, therefore, we have used homogeneous preparations of kidney enzyme to examine a group of potential neuropeptide substrates. The kinetic parameters show a wide range of values among the substrates tested. Our findings confirm that a free carboxy group at the $C$-terminus is not a prerequisite for efficient hydrolysis, and emphasize the role played by side chains of amino acid residues, other than those adjacent to the bond hydrolysed, in determining the susceptibility of the substrate to attack.

A number of selective inhibitors of endopeptidase-24.11 have been developed in order to evaluate the role of this enzyme in neuropeptide metabolism. Thiorphan has particularly been used in this context (Roques et al., 1980), and apparently displays anti-nociceptive properties (Patey et al., 1981 ; Algeri et al., 1981). Since endopeptidase24.11 and peptidyldipeptidase can each hydrolyse the $\mathrm{Gly}^{3}-\mathrm{Phe}^{4}$ bond of enkephalin (Benuck \& Marks, 1979; Fulcher et al., 1982; Schwartz, 1983) and they share some common mechanistic features, we have also compared the potency and selectivity of some inhibitors of pig kidney endopeptidase-24.11 and peptidyldipeptidase.

\section{Experimental}

\section{Materials}

Except where stated, peptides and peptide analogues were obtained from Cambridge $\mathrm{Re}$ search Biochemicals (Harston, Cambridge, U.K.) and their purity was routinely checked by h.p.l.c. The double-bond isostere of enkephalin (compound 3; Hann et al., 1982) was provided by Professor P. G. Sammes (Department of Organic Chemistry, University of Leeds). The 'enzymeresistant analogue' of substance $\mathbf{P}$ (DiMeC7; pGlu - Gln - Phe - MePhe - MeGly - Leu - MetNH $_{2}$ ) (Sandberg et al., 1981) was a gift from Dr. B. Sandberg (M.R.C. Neurochemical Pharmacology Unit, Cambridge, U.K.). Hip-His-Leu and hippuric acid were from Sigma Chemical Co. retroThiorphan $\left[(R, S)-\mathrm{HS}-\mathrm{CH}_{2}-\mathrm{CH}\left(\mathrm{CH}_{2}-\mathrm{C}_{6} \mathrm{H}_{5}\right)-\right.$ NHCO- $\mathrm{CH}_{2}-\mathrm{CO}_{2} \mathrm{H}$; Roques et al., 1983] was generously given by Dr. B. P. Roques (Départment de Chimie Organique, C.N.R.S., Paris, France). The endopeptidase inhibitors UK55076 (Mumford et al., 1982), CPAB (Almenoff \& Orlowski, 1983) and [ Gly-1-14 C]hippuryl-L-histidyl-L-leucine (NEC 746; New England Nuclear) were provided by Dr. G. Samuels (Pfizer Central Research, Sandwich, Kent, U.K.). The peptidyldipeptidase inhibitor MK422 (Patchett et al., 1980) was provided by Merck, Sharp and Dohme (Hoddesdon, Herts., U.K.). Cholecystokinin derivatives and the peptidyldipeptidase inhibitors SQ14225 (captopril) and SQ20881 (Teprotide) were gifts from the Squibb Institute for Medical Research (Princeton, NJ, U.S.A.). Other materials were from sources previously noted (Fulcher et al., 1982; Matsas et al., 1983; Relton et al., 1983). 


\section{Assay of endopeptidase-24.11}

Routine assays of the endopeptidase employed [D-Ala ${ }^{2}$, Leu $^{5}$ ]enkephalin $(1 \mathrm{mM})$ as substrate and $0.1 \mathrm{M}$-Tris/HCl buffer, pH 7.4 (Matsas et al., 1983). The peptide products of the reaction (Tyr-D-AlaGly and Phe-Leu) were resolved and quantified by h.p.l.c. For assay of the hydrolysis of other peptides a similar method was employed, although the h.p.l.c. conditions for peptide separation depended upon the particular peptides and their hydrolysis products (see the legend to Table 1).

\section{Assay of peptidyldipeptidase}

In monitoring the purification of this enzyme a radiochemical assay was employed. The incubation mixture $(125 \mu \mathrm{l})$ contained $1 \mathrm{mM}-\mathrm{Hip}-\mathrm{His}-\mathrm{Leu}$ $(0.01 \mu \mathrm{Ci}$ radioactivity), $30 \mathrm{~mm}-\mathrm{Hepes}, 90 \mathrm{~mm}-$ $\mathrm{NaCl}, 360 \mathrm{~mm}-\mathrm{Na}_{2} \mathrm{SO}_{4}$ and $0.6 \mathrm{~mm}-\mathrm{NaN}_{3}$. After incubation at $37^{\circ} \mathrm{C}$ for $60 \mathrm{~min}$, the reaction was terminated by the addition of $125 \mu \mathrm{l}$ of $1 \mathrm{M}-\mathrm{HCl}$ followed by $750 \mu$ l of ethyl acetate. After mixing, the phases were separated by centrifugation, and $0.5 \mathrm{ml}$ of the organic layer was assayed for radioactivity by liquid-scintillation counting. For inhibition experiments, a novel h.p.l.c. method was used to assay peptidyldipeptidase activity. Samples of the enzyme $(9 \mu \mathrm{g})$ in $0.1 \mathrm{M}$-Tris/HCl buffer, pH 8.3, containing $0.1 \mathrm{mM}$-bestatin, were incubated with Hip-His-Leu ( $5 \mathrm{mM})$ at $37^{\circ} \mathrm{C}$ in a total volume of $100 \mu \mathrm{l}$. The reaction was stopped by the addition of $30 \mu \mathrm{l}$ of acetic acid $(30 \%, \mathrm{v} / \mathrm{v})$, followed by centrifugation. A sample $(80 \mu \mathrm{l})$ of the supernatant was analysed by h.p.l.c. on a $\mu$ Bondapak $\mathrm{C}_{18}$ column (Waters Associates). A $15 \mathrm{~min}$ linear gradient of acetonitrile $(4.5-30 \%, \mathrm{v} / \mathrm{v})$ in $0.08 \%$ $\mathrm{H}_{3} \mathrm{PO}_{4}$ at $\mathrm{pH} 2.5$ was used for the separation, followed by $8 \mathrm{~min}$ elution at the final conditions. The flow rate was $1.5 \mathrm{ml} / \mathrm{min}$. Under these conditions the substrate (Hip-His-Leu) exhibited a retention time of $14.6 \mathrm{~min}$, and the products, HisLeu and hippurate, $3.8 \mathrm{~min}$ and $10.2 \mathrm{~min}$ respectively. The amount of hippurate formed during the incubation was calculated from its absorbance at $214 \mathrm{~nm}$.

\section{Assay of aminopeptidase N(EC 3.4.11.2)}

L-Alanine 4-methyl-7-coumarylamide was used as substrate as described previously (Fulcher \& Kenny, 1983).

\section{Purification of endopeptidase-24.11 from pig kidney}

The procedure for purification of the detergentsolubilized enzyme by immunoadsorbent chromatography has been described previously (Gee et al., 1983). The enzyme was apparently homogeneous by sodium dodecyl sulphate/polyacrylamide gel electrophoresis and contained no detectable aminopeptidase N (EC 3.4.11.2) or peptidyl dipeptidase activity.

\section{Purification of peptidyldipeptidase}

Peptidyldipeptidase was solubilized and partially purified from pig kidney $(100 \mathrm{~g})$ by the following procedure. A microsomal fraction was prepared (Fulcher \& Kenny, 1983) and resuspended in $200 \mathrm{ml}$ of $5 \mathrm{~mm}$-Tris/ $\mathrm{HCl}$ buffer, $\mathrm{pH} 8.0$ (at $37^{\circ} \mathrm{C}$ ). Trypsin was added $(1: 10, \mathrm{w} / \mathrm{w}$, of protein) and stirred for $2 \mathrm{~h}$ at $37^{\circ} \mathrm{C}$. After centrifugation at $30000 \mathrm{~g}$ for $90 \mathrm{~min}$, the supernatant fraction was applied to a DEAE-cellulose column (packed volume $100 \mathrm{ml}$ ) equilibrated with $5 \mathrm{mM}-\mathrm{Tris} / \mathrm{HCl}$ buffer, pH 7.4 (at $4^{\circ} \mathrm{C}$ ), and eluted by a linear gradient $(1000 \mathrm{ml})$ of $0-300 \mathrm{~mm}-\mathrm{NaCl}$ in the same buffer. The active fractions were collected and dialysed against $1 \mathrm{~mm}$-potassium phosphate buffer, pH 6.8, loaded on a column (volume $50 \mathrm{ml}$ ) of LKB HA-Ultrogel (hydroxyapatite) and eluted with a linear gradient (volume $600 \mathrm{ml}$ ) of $1-100 \mathrm{~mm}$ potassium phosphate buffer at the same $\mathrm{pH}$. The active fractions were pooled, dialysed against $5 \mathrm{mM}$-Tris/ $\mathrm{HCl}$ buffer, $\mathrm{pH} 7.4$ (at $4^{\circ} \mathrm{C}$ ) and concentrated on a small column $(0.5 \mathrm{ml})$ of DEAEcellulose by elution with $0.5 \mathrm{M}-\mathrm{NaCl}$ in $5 \mathrm{mM}$ Tris/HCl buffer, $\mathrm{pH}$ 7.4.

\section{Hydrolysis of peptides}

Samples of kidney endopeptidase (10-100ng) were allowed to react.with the various peptides or peptide analogues. Products were analysed by h.p.l.c. and were identified either by using marker peptides or by collection of the individual product peaks and amino acid analysis of the corresponding peptides, as described previously (Matsas et al., 1983). For the kinetic studies, the concentration of peptide was varied over a 50-fold range and, with the exception of cholecystokinin-8, all values were obtained from two or more separate experiments. Where hydrolysis of the peptide could involve hydrolysis of more than one peptide bond in the substrate (e.g. substance $P$ ), the kinetic constants were determined from the initial rate of decrease in concentration of substrate. For most peptides studied, hydrolysis of a single peptide bond occurred under initial conditions, and in these cases the initial rate of product formation was used to calculate kinetic constants. When the two methods of calculation were compared, good agreement between the values ( $<15 \%$ variation) was obtained.

\section{Results}

\section{Purification and assay of peptidyldipeptidase}

The partial purification of peptidyldipeptidase was accomplished in two column-chromatogra- 
phic steps. The yield was $21 \%$, the specific activity was $20.7 \mu \mathrm{mol}$ (hippurate formation)/min per mg of protein, giving an enrichment of 90-fold compared with the homogenate. A trace of aminopeptidase activity $(0.48 \mu \mathrm{mol} / \mathrm{min}$ per $\mathrm{mg})$ was detected, but this was abolished by $0.1 \mathrm{~mm}$ bestatin. For inhibition studies, separation and quantification of the reaction products by h.p.l.c. proved to be particularly convenient and reproducible. A 100 pmol quantity of hippurate could be detected with this assay method, which was sufficiently sensitive to measure peptidyldipeptidase activity in brain membrane preparations.

\section{Kinetics of peptide hydrolysis by endopeptidase-24.11}

The specificity of pig kidney endopeptidase24.11 towards various substrates is detailed in Table 1. For all substrates examined, strict Michaelis-Menten kinetics were observed over a 50 -fold range of substrate concentration. Values for $k_{\text {cat. }}$ were calculated assuming a subunit $M_{\mathrm{r}}$ of 89000 for the pig kidney enzyme (Fulcher \& Kenny, 1983). $K_{\mathrm{m}}$ values were found to vary by a factor of more than 25-fold among the natural peptides, with the amidated undecapeptide, substance $\mathrm{P}$, possessing the lowest $K_{\mathrm{m}}(31.9 \mu \mathrm{M})$. Where identified, the sites of cleavage by the enzyme are listed in Table 2 . In the substrates studied, the primary specificity is consistent with hydrolysis occurring on the amino group at bonds involving hydrophobic residues, e.g. phenylalanine, leucine, tyrosine and isoleucine. A free $C$ terminus is by no means essential for hydrolysis to occur, since the deamidated analogue of substance $P$ was hydrolysed only slightly more efficiently than substance $P$ itself (Table 1 ).

\section{Inhibition of endopeptidase-24.11 and peptidyl- dipeptidase}

The inhibition curves of various inhibitors on kidney endopeptidase-24.11 and peptidyldipeptidase are compared in Fig. 1. Of the inhibitors tested, only CPAB selectively inhibited the endopeptidase with no detectable effect on peptidyldipeptidase. However, it was less potent than phosphoramidon or thiorphan, in agreement with reported $K_{\mathrm{i}}$ values: CPAB, 70nM (Almenoff \&

Table 1. Kinetics of hydrolysis of neuropeptides by endopeptidase-24.11

For assay conditions see the text. Peptide products were separated and quantified by h.p.l.c. A 15 min linear gradient of acetonitrile $(4.5-30 \%, \mathrm{v} / \mathrm{v})$ in $0.08 \% \mathrm{H}_{3} \mathrm{PO}_{4}$ at $\mathrm{pH} 2.5$, followed by elution for $5 \mathrm{~min}$ at final conditions, was used for all peptide substrates except the tachykinins and cholecystokinin-8. For these latter peptides a $20 \mathrm{~min}$ linear gradient of acetonitrile $(4.8-60 \%, \mathrm{v} / \mathrm{v})$ in $0.08 \% \mathrm{H}_{3} \mathrm{PO}_{4}$ at $\mathrm{pH} 2.5$ was employed, followed by elution for $5 \mathrm{~min}$ at final conditions. $K_{\mathrm{m}}$ values are given as mean \pm S.E.M. where $n \geqslant 3$.

Enkephalins and analogues

$\left[\mathrm{Leu}^{5}\right]$ enkephalin

$\left[\mathrm{Leu}^{5}\right]$ enkephalin (isostere)

$\left[\mathrm{D}-\mathrm{Ala}^{2}, \mathrm{Leu}^{5}\right.$ ]enkephalin

[Leu ${ }^{5}$ ]enkephalinamide

$\left[\mathrm{D}-\mathrm{Ala}^{2}, \mathrm{Leu}^{5}{ }^{5}\right.$ enkephalinamide

$\left[\right.$ Leu $^{5}$ ]enkephalin-Arg ${ }^{6}$

Dynorphin-(1-9)-peptide

[Met ${ }^{5}$ ]enkephalin

$\left[\mathrm{D}-\mathrm{Ala}^{2}, \mathrm{Met}^{5}\right.$ ]enkephalinamide

$\left[\mathrm{Met}^{5}{ }^{5}\right.$ enkephalin-Arg ${ }^{6}$

$\left[\mathrm{Met}^{5}\right.$ ]enkephalin-Arg ${ }^{6}-\mathrm{Phe}^{7}$

Tachykinins and analogues

Substance $\mathbf{P}$

Substance $\mathbf{P}$ (deamidated)

$\left[\mathrm{Nle}^{11}\right.$ ]substance $\mathrm{P}$

Physalaemin

$\mathrm{DiMeC7}$

Other peptides

Bradykinin

Neurotensin

Luliberin

Cholecystokinin-8

Cholecystokinin-8 sulphated

$$
K_{\mathrm{m}}(\mu \mathrm{M})
$$

$$
86.2 \pm 10.7(n=3)
$$$$
110(n=2)
$$$$
88.0 \pm 4.5(n=6)
$$$$
680(n=2)
$$$$
773 \pm 23(n=3)
$$$$
111 \pm 4.1(n=3)
$$$$
219(n=2)
$$$$
62(n=2)
$$

$432+14(n=3)$

$38.5 \pm 1.6(n=4)$

$50.4 \pm 1.0(n=5)$

$31.9 \pm 3.1(n=5)$

$37.8(n=2)$

$83.8(n=2)$

$105.9(n=2)$

$2567 \pm 163(n=3)$

$92.2 \pm 9.5(n=6)$

$78.0 \pm 8.1(n=3)$

$755(n=2)$

$67.4(n=1)$

$296(n=1)$

$$
\underset{\left(\min ^{-1}\right)}{k_{\text {cat. }}}
$$

3781

2371

5645

1129

1659

4610

5340

2597

6132

2062

5198

5062

7666

7096

7379

11837

6364

1280

840

1924

8893 $k_{\text {cat. }} / K_{\mathrm{m}}$ relative to

$$
\begin{array}{cc}
k_{\text {cat. }} / K_{\mathrm{m}} & \begin{array}{c}
\text { that for } \\
\left(\min ^{-1} \cdot \mu \mathrm{M}^{-1}\right)
\end{array} \\
{\left[\mathrm{Leu}^{5}\right] \text { enkephalin }}
\end{array}
$$$$
43.9
$$$$
21.6
$$$$
64.2
$$$$
1.7
$$$$
2.1
$$$$
41.7
$$$$
24.4
$$$$
41.9
$$$$
14.2
$$$$
53.6
$$$$
117.4
$$$$
158.7
$$$$
202.8
$$$$
84.7
$$$$
69.7
$$$$
4.6
$$$$
1.00
$$$$
0.49
$$$$
1.46
$$$$
0.039
$$$$
0.048
$$$$
0.95
$$$$
0.56
$$$$
0.95
$$$$
0.32
$$$$
1.22
$$$$
2.67
$$$$
3.62
$$$$
4.62
$$$$
1.93
$$$$
1.59
$$$$
0.10
$$

69.0

1.57

16.4

0.37

1.1

0.025

28.5

30.0 
Table 2. Sites of hydrolysis of neuropeptides by endopeptidase-24.11

The scissile bonds were identified as follows: samples of purified endopeptidase- 24.11 were incubated with the various peptides either under initial-rate conditions ( $<10 \%$ substrate hydrolysis) or such that $60-70 \%$ hydrolysis of the substrate occurred. Peptide products were analysed by h.p.l.c. and identified as described in the text. $\downarrow$ and $\downarrow$ represent sites of cleavage under initial-rate conditions and after extensive substrate hydrolysis respectively. The one-letter code for amino acids [see Biochem. J. (1984) 219, 366-368] is used, and $\mathrm{NH}_{2}$ at the $C$-terminus indicates an amidated residue; the abbreviations $\mathrm{dA}$ and $\mathrm{Nl}$ refer to $\mathrm{D}$-alanine and norleucine respectively.

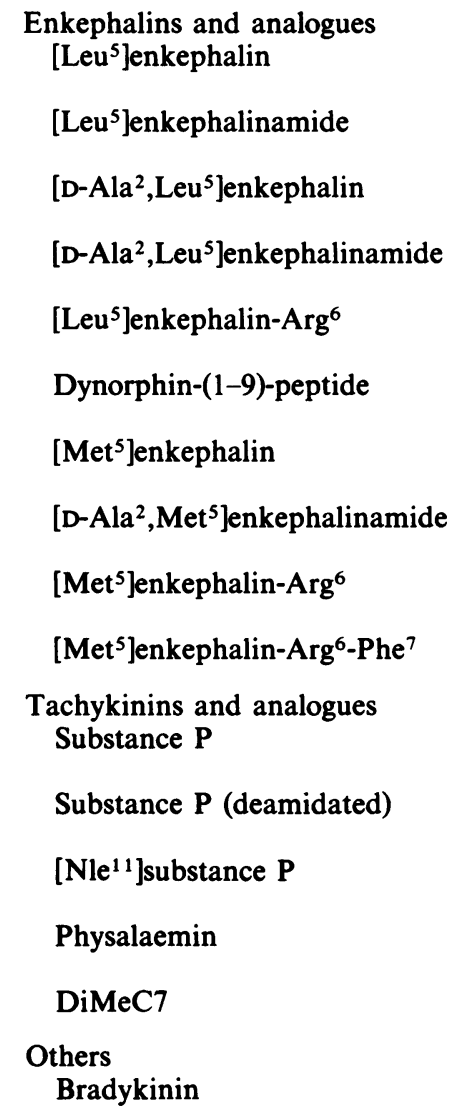

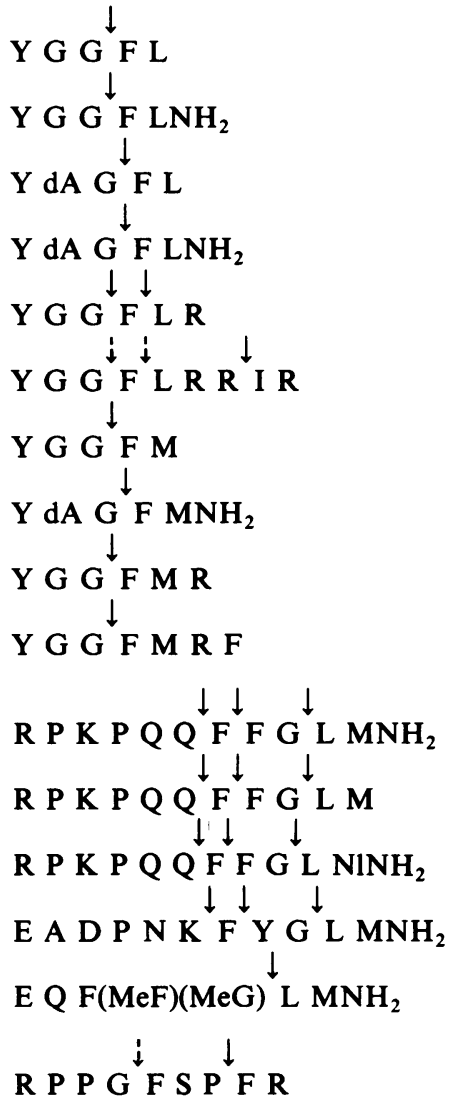

Orlowski, 1983); phosphoramidon, 2 nm (Kenny, 1977); thiorphan, $2 \mathrm{~nm}$ (Roques et al., 1983). The various inhibitors displayed differing degrees of selectivity, with thiorphan being least effective at distinguishing between the two enzymes (Fig. 1). Captopril $\left(I_{50}=9 \mathrm{nM}\right.$, results not shown) and SQ20881 $\left(I_{50}=60 \mathrm{nM}\right.$, results not shown $)$ did not inhibit endopeptidase-24.11 at concentrations up to $0.1 \mathrm{mM}$.

\section{Discussion}

Much attention has focused on the hydrolysis of the $\mathrm{Gly}^{3}-\mathrm{Phe}^{4}$ bond of enkephalin by brain membrane preparations, particularly with a view to the development of selective inhibitors. There is scant information available on the kinetics and specificity of hydrolysis of other biologically active peptides, particularly with a pure enzyme prepara- tion. Now that the identity of kidney and brain endopeptidase-24.11 has been unequivocally established (Matsas et al., 1983; Relton et al., 1983), we have used the much more abundant kidney enzyme for the specificity studies on neuropeptides described in the present paper. The use of our immunoadsorbent column allows $2 \mathrm{mg}$ batches of homogeneous enzyme to be prepared routinely from pig kidney.

The present data reveal that a wide range of peptides of diverse structures are metabolized, several of them more efficiently than enkephalin itself. In all the substrates examined, hydrolysis occurs at the bond involving the amino group of a hydrophobic residue. Since an internal hydrophobic residue is a relatively common feature among biologically active peptides, endopeptidase-24.11 has the required specificity to play a general role in the hydrolysis of biologically active peptides at the 


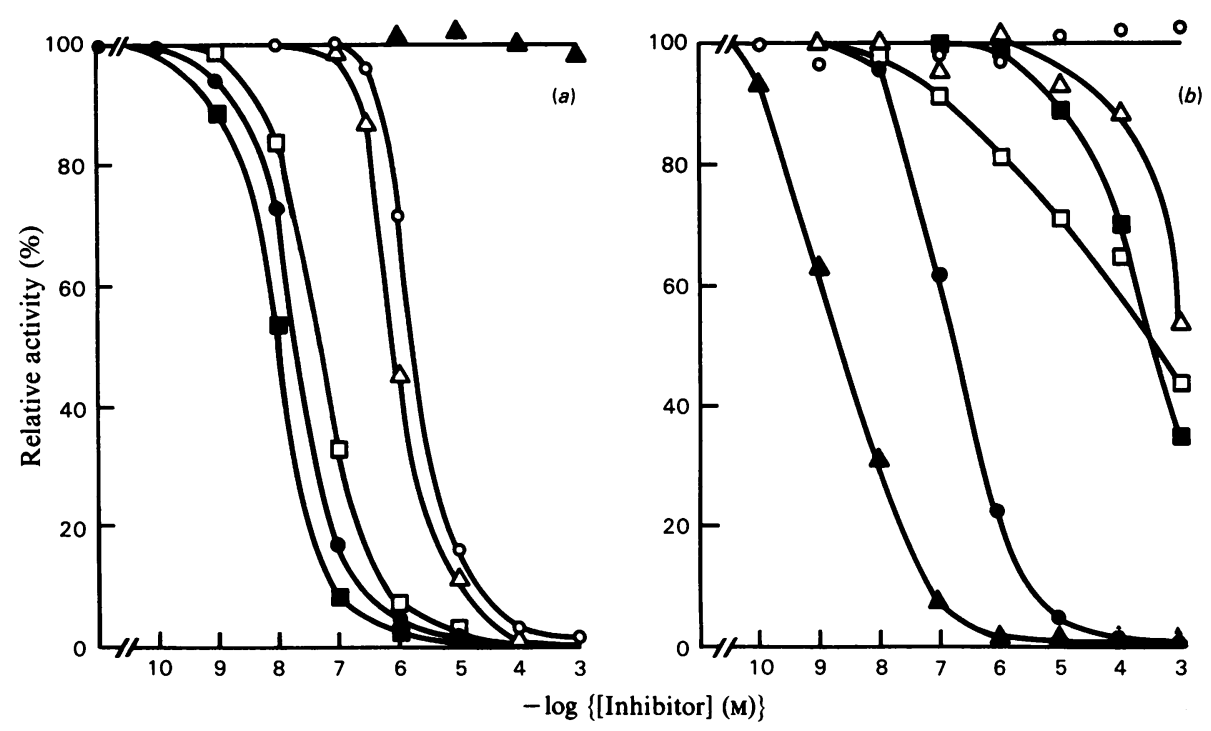

Fig. 1. Inhibition of kidney endopeptidase-24.11 and peptidyldipeptidase $A$

(a) Inhibition of endopeptidase-24.11; (b) inhibition of peptidyldipeptidase A. The inhibitors used were: $O, C P A B$; $\triangle$, UK55076; $\square$, retro-thiorphan;, thiorphan; $\triangle$, MK 422; $\boldsymbol{a}$, phosphoramidon. The effectors were present in the incubation mixture at the concentration shown and were added before the substrate, but no preincubation was used. Endopeptidase-24.11 was assayed with [D-Ala $\left.{ }^{2}, \mathrm{Leu}^{5}\right]$ enkephalin and peptidyldipeptidase A with Hip-His-Leu as substrate (see the Experimental section for details).

cell surface, as we have suggested previously (Matsas et al., 1983). The use of selective enzyme inhibitors and a knowledge of the precise cellular and tissue location of endopeptidase-24.11 should help to define more clearly its precise physiological roles.

\section{Hydrolysis of enkephalins and analogues}

Malfroy \& Schwartz (1982) have argued that the enzyme hydrolysing the $\mathrm{Gly}^{3}-\mathrm{Phe}^{4}$ bond of enkephalin functions as a peptidyldipeptidase hydrolysing a $C$-terminal dipeptide from the substrate. In this respect, the enzyme would resemble angiotensin I-converting enzyme. The evidence for this contention was primarily that enkephalin analogues in which the $C$-terminal residue is amidated exhibited much larger $K_{\mathrm{m}}$ values than did the corresponding free acids. This observation is confirmed in the present study with regard to both enkephalins and their amidated derivatives. However, examination of a wider range of enkephalin analogues reveals that the enzyme can function equally well as an endopeptidase. For example, enkephalins with a $C$-terminal extension, e.g. $\left[\mathrm{Leu}^{5}\right]$ enkephalin-Arg ${ }^{6}, \quad\left[\mathrm{Met}^{5}{ }^{5}\right.$ enkephalin-Arg ${ }^{6}$ and $\left[\mathrm{Met}^{5}\right]$ enkephalin-Arg ${ }^{6}-\mathrm{Phe}^{7}$, are metabolized at least as efficiently as is the parent peptide, with hydrolysis still occurring at the $\mathrm{Gly}^{3}-\mathrm{Phe}^{4}$ bond. With [Met ${ }^{5}$ ]enkephalin-Arg ${ }^{6}$ as a substrate there was no detectable peptidyldipeptidase activ- ity at the $\mathrm{Phe}^{4}-\mathrm{Met}^{5}$ bond. The isosteric analogue of $\left[\mathrm{Leu}^{5}\right]$ enkephalin in which the $\mathrm{Tyr}^{1}-\mathrm{Gly}^{2}$ peptide bond is replaced by a carbon-carbon double bond (Hann et al., 1982) is, surprisingly, somewhat less efficient as a substrate than is either $\left[\mathrm{Leu}^{5}\right]$ enkephalin or $\left[\mathrm{D}-\mathrm{Ala}^{2}, \mathrm{Leu}^{5}\right]$ enkephalin. This may reflect a decreased potential for hydrogen-bond formation between substrate and enzyme, and emphasizes the secondary role of amino acid residues several positions removed from the hydrolysis site.

\section{Hydrolysis of tachykinins}

We had previously reported that brain synaptic membranes hydrolysed substance $\mathbf{P}$ and that this hydrolysis was inhibited by phosphoramidon and by a polyclonal antiserum to kidney endopeptidase-24.11 (Matsas et al., 1983). These observations revealed the potential of the endopeptidase for inactivation of neuropeptides other than the enkephalins. Although substance $P$ is amidated at the $C$-terminus, it exhibits the lowest $K_{\mathrm{m}}$ value of all the peptides that we have tested (Table 1), further emphasizing the endopeptidase rather than peptidyldipeptidase nature of the enzyme. There is little difference in efficiency of hydrolysis between substance $P$ and its non-amidated analogue. The analogue $\left[\mathrm{Nle}^{11}\right]$ substance $\mathrm{P}$ and another tachykinin, physalaemin, are also better substrates for the enzyme than are the enkephalins (on the basis 
of $k_{\text {cat. }} / K_{\mathrm{m}}$ values). Although hydrolysis can occur adjacent to all three of the hydrophobic residues in the tachykinins, the predominant cleavage occurs at Gly $^{9}-$ Leu $^{10}$ (Matsas et al., 1983; and Table 2). The compound DiMeC7 has been designed as an 'enzyme-resistant' analogue of substance P (Sandberg et al., 1981). The methylation of the $\mathrm{NH}$ groups of the peptide bonds involving the $\mathrm{Phe}^{8}$ and $\mathrm{Gly}^{9}$ residues prevented hydrolysis at the $\mathrm{Phe}^{7}$ $\mathrm{Phe}^{8}$ and $\mathrm{Phe}^{8}-\mathrm{Gly}^{9}$ bonds but still permitted hydrolysis at the $\mathrm{Gly}^{9}-\mathrm{Leu}^{10}$ bond, albeit slowly. DiMeC7 is almost 40 -fold less efficient as a substrate than is substance $\mathbf{P}$ itself. Pig caudate synaptic membranes are also able to hydrolyse $\mathrm{DiMeC7}$ at the Gly ${ }^{9}-\mathrm{Leu}^{10}$ bond, and this hydrolysis is inhibited by phosphoramidon (R. Matsas, A. J. Kenny \& A. J. Turner, unpublished work). These results suggest that amino acid substitutions at the 10-position of substance $P$ may produce more effective enzyme-resistant analogues of this neuropeptide.

\section{Other peptides}

We have examined a limited number of other biologically active peptides as potential substrates for pig kidney endopeptidase-24.11. In all cases the presence of an internal hydrophobic residue determines susceptibility to hydrolysis. However, marked differences in the relative rates of hydrolysis are observed. The hypothalamic peptide luliberin (luteinizing-hormone-releasing hormone) is blocked at both $N$ - and $C$-termini and contains several internal hydrophobic residues. Its physiological inactivation must therefore involve the action of an endopeptidase, yet luliberin is a poor substrate for endopeptidase-24.11 compared with enkephalin or substance P. A phosphoramidoninsensitive endopeptidase has been detected in synaptic membranes (Relton et al., 1983) and this may be of relevance to the metabolism of luliberin. Bradykinin, neurotensin and cholecystokinin are all hydrolysed by endopeptidase- 24.11 , and the efficiency of hydrolysis of these peptides is not markedly different from that of enkephalin.

\section{Inhibition of endopeptidase-24.11 and peptidyl- dipeptidase}

The similarities in mechanism, and perhaps structure, of endopeptidase-24.11 and peptidyldipeptidase provide medicinal chemists with a considerable challenge for the design of selective inhibitors. It is clear that a number of compounds developed as inhibitors of endopeptidase-24.11 also inhibit peptidyldipeptidase. On the other hand, inhibitors of peptidyldipeptidase that contain a proline residue at the $C$-terminus, e.g. captopril, SQ20881 and MK422, appear to be highly selective and do not significantly affect endopeptidase-24.11 at concentrations of $0.1 \mathrm{mM}$. The thiol compound thiorphan (Roques et al., 1980), which has been widely used as an inhibitor of the endopeptidase, is far from ideal because of its lack of selectivity and its susceptibility to oxidation. Experiments designed to examine the physiological role of the enzyme with the use of this inhibitor (Roques et al., 1980; Algeri et al., 1981; Patey et al., 1981; Chaillet et al., 1983) should therefore be interpreted with caution. Retroinversion of the $C$-terminal amide bond of thiorphan produces the compound retro-thiorphan (Roques et al., 1983), which, although more selective than thiorphan, is still less stable, less potent and less selective than is phosphoramidon (Fig. 1). This natural product was originally shown to be a potent inhibitor of endopeptidase-24.11 in 1977 (Kenny, 1977). The features exploited for the design of peptidase inhibitors by Patchett et al. (1980), Mumford et al. (1982) and Almenoff \& Orlowski (1983) should lead to the development of a range of selective and potent inhibitors of endopeptidase-24.11 in vivo, allowing studies of the physiological roles of this enzyme in different tissues.

\section{General comments}

These studies and those of other groups may permit some general comments on the specificity requirements of endopeptidase-24.11. (1) Efficient hydrolysis occurs at bonds involving the amino group of hydrophobic residues (provided that they are not $\mathrm{N}$ - or $\mathrm{C}$-terminal). In the peptides we have examined (Table 2), the residues involved are phenylalanine (in most of the peptides), leucine (in [Leu ${ }^{5}$ ]enkephalin-Arg ${ }^{6}$, dynorphin-(1-9)-peptide and the tachykinins $\}$, isoleucine [in dynorphin-(19)-peptide] and tyrosine (in physalaemin). Orlowski \& Wilk (1981) and Almenoff \& Orlowski (1983) observed hydrolysis adjacent to an alanine residue in a synthetic substrate (benzoyl-Gly-ArgArg-Ala-2-naphthylamide) but with relatively low efficiencies. (2) The influence of residues remote from the scissile bond is more difficult to predict, though these effects are very important in determining the efficiency of hydrolysis. Most information relates to side chains occupying the $P_{1}, P_{2}, P_{3}$ and $\mathrm{P}_{4}$ positions rather than those on the carboxy side of the hydrophobic residue. Arginine residues in $P_{1}$ and $P_{2}$ favoured efficient hydrolysis (Orlowski \& Wilk, 1981; Almenoff \& Orlowski, 1983) and this is borne out in the case of dynorphin, where the $\mathrm{Arg}^{7}-\mathrm{Ile}^{8}$ bond was rapidly hydrolysed compared with the $\mathrm{Gly}^{3}-\mathrm{Phe}^{4}$ or $\mathrm{Phe}^{4}-\mathrm{Leu}^{5}$ bonds. However, the presence of paired basic residues within neuropeptides is relatively rare, since these are commonly the sites for proteolytic processing of the precursor peptide (Loh et al., 1984; Turner, 
1984). The formulation of more precise rules requires extensive kinetic studies on a wider range of synthetic peptides than have so far been reported.

We thank the Medical Research Council for financial support and Mrs. Jean Ingram and Mr. John Hryszko for their technical assistance.

\section{References}

Algeri, S., Altstein, M., de Simone, G. M. \& Guardabasso, V. (1981) Eur. J. Pharmacol. 74, 261-262

Almenoff, J. \& Orlowski, M. (1983) Biochemistry 22, 590-599

Almenoff, J. \& Orlowski, M. (1984) J. Neurochem. 42, $151-157$

Benuck, M. \& Marks, N. (1979) Biochem. Biophys. Res. Commun. 88, 215-221

Chaillet, P., Marçais-Collado, H., Costentin, J., Yi, C.-C., de la Baume, S. \& Schwartz, J. C. (1983) Eur. J. Pharmacol. 86, 329-336

Fournié-Zaluski, M.-C., Soroca-Lucas, E., Waksman, G., Llorens, C., Schwartz, J.-C. \& Roques, B. P. (1982) Life Sci. 31, 2947-2954

Fulcher, I. S. \& Kenny, A. J. (1983) Biochem. J. 211, 743753

Fulcher, I. S., Matsas, R., Turner, A. J. \& Kenny, A. J. (1982) Biochem. J. 203, 519-522

Gee, N. S., Matsas, R. \& Kenny, A. J. (1983) Biochem. J. 214, 377-386

Hann, M. M., Sammes, P. G., Kennewell, P. D. \& Taylor, J. B. (1982) J. Chem. Soc. Perkin Trans. $1307-$ 314

Hudgin, R. L., Charleson, S. E., Zimmerman, M., Mumford, R. \& Wood, P. L. (1981) Life Sci. 29, 25932601
Kenny, A. J. (1977) in Proteinases in Mammalian Cells and Tissues (Barrett, A. J., ed.), pp. 393-444, Elsevier/ North-Holland Biomedical Press, Amsterdam

Kenny, A. J. \& Fulcher, I. S. (1983) Ciba Found. Symp. 95, 12-33

Kerr, M. A. \& Kenny, A. J. (1974) Biochem. J. 137, 477488

Loh, Y. P., Brownstein, M. J. \& Gainer, H. (1984) Annu. Rev. Neurosci. 7, 189-222

Malfroy, B. \& Schwartz, J.-C. (1982) Life Sci. 31, 17451748

Malfroy, B., Swerts, J. P., Guyon, A., Roques, B. P. \& Schwartz, J. C. (1978) Nature (London) 276, 523-526

Matsas, R., Fulcher, I. S., Kenny, A. J. \& Turner, A. J. (1983) Proc. Natl. Acad. Sci. U.S.A. 80, 3111-3115

Mumford, R. A., Zimmerman, M., ten Broeke, J., Taub, D., Joshua, H., Rothrock, J. W., Hirshfield, J. M., Springer, J. P. \& Patchett, A. A. (1982) Biochem. Biophys. Res. Commun. 109, 1303-1309

Orlowski, M. \& Wilk, S. (1981) Biochemistry 20, 49424950

Patchett, A. A., Harris, E., Tristram, E. W. et al. (1980) Nature (London) 288, 280-283

Patey, G., de la Baume, S., Schwartz, J.-C., Gros, C., Roques, B., Fournié-Zaluski, M.-C. \& Soroca-Lucas, E. (1981) Science 212, 1153-1155

Relton, J. M., Gee, N. S., Matsas, R., Turner, A. J. \& Kenny, A. J. (1983) Biochem. J. 215, 519-523

Roques, B. P., Fournié-Zaluski, M. C., Soroca, E., Lecomte, J. M., Malfroy, B., Llorens, C. \& Schwartz, J.-C. (1980) Nature (London) 288, 286-288

Roques, B. P., Lucas-Soroca, E., Chaillet, P., Costentin, J. \& Fournié-Zaluski, M. C. (1983) Proc. Natl. Acad. Sci. U.S.A. 80, 3178-3182

Rush, R. S. \& Hersh, L. B. (1982) Life Sci. 31, 445-451

Sandberg, B. E. B., Lee, C.-M., Hanley, M. R. \& Iversen, L. L. (1981) Eur. J. Biochem. 114, 329-337

Schwartz, J.-C. (1983) Trends Neurosci. 6, 45-48

Schwartz, J.-C., Malfroy, G. \& de la Baume, S. (1981) Life Sci. 29, 1715-1740

Turner, A. J. (1984) Trends Neurosci. 7, 258-260 